IZA DP No. 8749

Neighborhood Decline and the Economic Crisis

Merle Zwiers

Gideon Bolt

Maarten van Ham

Ronald van Kempen

December 2014 


\title{
Neighborhood Decline and the Economic Crisis
}

\author{
Merle Zwiers \\ Delft University of Technology
}

Gideon Bolt

Utrecht University

\author{
Maarten van Ham \\ Delft University of Technology and IZA
}

Ronald van Kempen

Utrecht University

\section{Discussion Paper No. 8749 \\ December 2014}

\author{
IZA \\ P.O. Box 7240 \\ 53072 Bonn \\ Germany \\ Phone: +49-228-3894-0 \\ Fax: +49-228-3894-180 \\ E-mail: iza@iza.org
}

Any opinions expressed here are those of the author(s) and not those of IZA. Research published in this series may include views on policy, but the institute itself takes no institutional policy positions. The IZA research network is committed to the IZA Guiding Principles of Research Integrity.

The Institute for the Study of Labor (IZA) in Bonn is a local and virtual international research center and a place of communication between science, politics and business. IZA is an independent nonprofit organization supported by Deutsche Post Foundation. The center is associated with the University of Bonn and offers a stimulating research environment through its international network, workshops and conferences, data service, project support, research visits and doctoral program. IZA engages in (i) original and internationally competitive research in all fields of labor economics, (ii) development of policy concepts, and (iii) dissemination of research results and concepts to the interested public.

IZA Discussion Papers often represent preliminary work and are circulated to encourage discussion. Citation of such a paper should account for its provisional character. A revised version may be available directly from the author. 
IZA Discussion Paper No. 8749

December 2014

\section{ABSTRACT}

\section{Neighborhood Decline and the Economic Crisis}

Neighborhood decline is a complex and multidimensional process. National and regional variation in economic and political structures (including variety in national welfare state arrangements), combined with differences in neighborhood history, development and population composition, makes it extremely difficult to identify a unilateral process of neighborhood decline over time. Some scholars have tried to develop all-encompassing models to explain neighborhood decline; others have studied more deeply the relevance of a limited number of factors and developments in processes of decline. The literature has paid little attention to the influence of economic development on neighborhood development, and surprisingly, few studies have focused on the effects of the economic crisis on urban neighborhoods. The recent global economic and financial crisis affected many European and North-American cities in terms of growing unemployment levels and rising poverty in concentrated areas. At the same time, urban investments such as urban restructuring and neighborhood improvement programs have decreased, or come to a halt altogether. By reviewing existing literature, this paper aims to contribute to an understanding of neighborhood decline in light of the economic crisis. By formulating ten hypotheses about the ways in which the economic crisis might interact with processes of neighborhood decline, this paper aims to push the debate on neighborhood decline forward and calls for more contextualized research on neighborhood change. We will highlight challenges for future research and point to factors that need to be taken into consideration in a post-crisis society.

JEL Classification: $\quad$ I32, I38, O18, R23

Keywords: neighborhood decline, economic crisis, neighborhood regeneration, policy, housing market

Corresponding author:

Merle Zwiers

OTB - Research for the Built Environment

Faculty of Architecture and the Built Environment

Delft University of Technology

PO Box 5030

2600 GA Delft

The Netherlands

E-mail: m.d.zwiers@tudelft.nl 


\section{Introduction}

The global financial and economic crisis, which started in 2008, has had a major impact on our societies.The declining economy and growing unemployment levels were followed by major budget cuts on social provisions. This has led to an absolute growth in the number of disadvantaged households and has further deteriorated the disadvantaged situation of many poor households on both sides of the Atlantic. The average income of the total population across the OECD countrieshas stagnated between 2007 and 2010, while the average income of households in the lowest income decile has experienced an annual decline of 2 percent (OECD, 2013). In many countries the financial crisis has also had a major impact on the housing market, evidenced by a large drop in houseprices and in the number of sales in both existing housing stocks and new-build housing (van der Heijden et al., 2011).

The crisis hit almost every homeowner or renter in one way or another. The consequences of the crisis are probably most felt by disadvantaged households in the most disadvantaged neighborhoods of our cities. In the United States, for instance, sub-prime and predatory lendinghave particularly affected low-income and minority households, leading to a concentration of foreclosures in disadvantaged neighborhoods (Aalbers, 2009). While deprived neighborhoods have received continuous attention in academic and political debates over the past hundred years or so, the recent crisis has intensified this attentionas neighborhoods have been placed at the heart of our understanding of inequality. The European Commission, for example, has argued that inequality has a particular spatial outcome in the sense that the poorest people increasingly live in the most disadvantaged neighborhoods (European Commission, 2010). In the Europe 2020 Strategy, the European Commission pays particular attention to the territorial dimension of poverty, as they argue that "the nature of disadvantage affecting people in situations of poverty is influenced by the area where they live" (European Commission, 2010, p. 13).

While there is much debate on the importance of these so-called 'neighborhood effects' (e.g. Oreopoulos, 2003; Bolster et al., 2007; Chesire, 2007; Van Ham and Manley, 2010; 2012; Galster, 2012; Van Kempen and Wissink, 2014), the statement from the European Commission indicates that disadvantaged neighborhoods have been put back on the political agenda in light of the financial crisis. While it is fair to say that we are still grasping to understand the long-term effects of the crisis on our cities and communities, there are already many studies that focus on the effects of the economic crisis on, for example, health outcomes (e.g., Gili et al., 2012), social policies (e.g., OECD, 2014), inequality (e.g., Immervoll et al., 2011; Bellman and Gerner, 2011) and on the housing market (e.g., Van der Heijden et al., 2011). But interestingly enough, there are very few recent empirical studies that focus on the relation between the economic crisis and neighborhood decline.

The recent economic crisis does raise new questions about the future development of neighborhoods. Can we expect an increasing speed of decline in some neighborhoods? Which neighborhoods, and maybe more importantly which residents, will particularly suffer from such decline? How will the crisis on the housing market influence neighborhoods, both in terms of their physical characteristics and their population composition? Increasing unemployment in many cities forces homeowners to sell their dwellings below market value; will this lead to neighborhood decline and how does this affect surrounding properties? At the same time, increasing unemployment combined with austerity measures creates a large group of households that is in need of affordable (social) housing. However, in many European and American cities the social housing stock is limited (and becomes even smaller because of demolition and selling off parts of the stock) and waiting lists are long. Will this lead to increasing (illegal) 'milking' of properties, fuelling neighborhood decline? And ultimately, 
will the economic crisis lead to increasing neighborhood decline and increasing levels of income and ethnic segregation?

In view of these concerns, this article sets out to identify factors that affect neighborhood decline in light of the (aftermath of the) economic crisis. The main goal of this article is to push the debate on neighborhood decline forward and to call for more research on the spatial consequences of the economic crisis, and, as such, on the territorial dimensions of increasing inequality. Instead of trying to create another all-encompassing, universal model of neighborhood decline, this article aims to identify factors that can potentially play a role in processes of neighborhood decline in different contexts. Our argument is structured around the assumption that the housing and economic crisis has a (potential) effect on each of these factors. For each factor we formulate a hypothesis about how the crisis is expected to fuel neighborhood decline.

We will start with a short discussion of definitions of neighborhoods and neighborhood decline. This is followed by a section on the geographies of the economic crisis. We will then pick out important elements from existing studies which will be followed by hypotheses about the ways in which these elements relate to the economic crisis. A total of ten hypotheses will be formulated about the ways in which the economic crisis interacts with neighborhood decline. The conclusion brings our arguments together and calls for more contextualized longitudinal research on the individual level.

\section{Defining Neighborhoods and Neighborhood Decline}

\section{Neighborhood}

What is a neighborhood? Numerous definitions exist. According to Galster (2001, p. 2111), the term neighborhood is like pornography: hard to define precisely, but everyone knows (more or less) what it is when they see it. Asking interviewees about their neighborhood made it clear that self-definitions often work very well as the outcomes show much overlap between interviewees.Most people can define their residential neighborhood by referring to hard borders such as roads, rivers and railway lines. Apart maybe from homogeneous American suburbs, definitions of neighborhoods based on similarity in housing types, such as rental dwellings or single-family owner-occupied houses, are less easy. This is especially the case in mixed-housing areas. Some definitions of neighborhood are based on distance: the neighborhood then covers the area from which you can reach important destinations (primary school, shops, and friends) within walking distance (e.g. Morris and Hess, 1976). In some definitions authors refer explicitly to the existence of social bonds in the area (e.g. Warren, 1981; Downs, 1981; and Schoenberg, 1979, all cited in Galster, 2001): a neighborhood is not a neighborhood without such social bonds. Galster defines neighborhood as “... bundles of spatially based attributes associated with clusters of residences, sometimes in conjunction with other land uses" (Galster, 2001, p. 2112). The "spatially based attributes" refer to, for example, the characteristics of buildings, and infrastructural, demographic, class status, social-interactive, and sentimental characteristics.

In practice, the operationalization of neighborhoods is often dependent on the availability and quality of data. Although in recent years data has become available on a low spatial level (such as 100x100 meters grids; see van Ham et al., 2014) which allow researchers to construct their own neighborhoods, many researchers actually rely on existing standard administrative boundaries. Such areas are usually pre-defined by historical, structural and infrastructural characteristics. Within such areas other characteristics can then be measured, such as housing quality, house prices, demographic and economic characteristics. However, the use of existing administrative boundaries may complicate neighborhood 
research because boundaries and definitions can change over time; are likely to differ between countries; and may not reflect social reality (cf. Sampson et al., 2002). For our purposes it is sufficient to use a rather general and pragmatic definition of neighborhood: a neighborhood is a meaningful spatial unit for which a number of physical, economic and social characteristics can be measured. The size of a neighborhood may vary per city.

\section{Neighborhood Decline}

Neighborhoods can develop in different directions: a neighborhood can be very stable over years or even decades, housing similar types of people, with similar demographic and economic characteristics. Neighborhoods can experience upgrading, indicated by, for example, rising house prices, an outflow of low income households and an inflow of more affluent households. The extensive literature on gentrification (e.g., Lees, 2008; Doucet, 2014) documents such processes very well. Neighborhoods can also show a process of downgrading, indicated by declining house prices, an inflow of low-income households and an outflow of more affluent households. However, neighborhood upgrading and downgrading are not mutually exclusive processes and can take on different forms in different contexts. Upgrading and downgrading of neighborhoods do not necessarily have external causes. Insitu changes such as an aging population, processes such as fertility and mortality within the neighborhood, and changes in the employment status of the sitting population might also be causes of change. Incumbent up- and downgrading refers to the changing socioeconomic profile of the resident population within an area (e.g., Teernstra, 2014). It is an empirical question how important external forces and internal developments are for the developments of neighborhoods, this can differ per country, city, or even per neighborhood. To empirically address such questions there is a need for individual-level data over longer periods of time. Such data have not always been available in all countries, however, as better data becomes available, researchers should aim to take a richer array of longitudinal individual and spatial variables into account (Van Ham and Manley, 2012).

In this paper, we use a broad definition of neighborhood decline: any negative development in the physical, social or economic conditions of a neighborhood as experienced by its residents or other stakeholders. We especially regard the view of residents important because policy makers often have different associations with neighborhood decline than residents. For example, residents may feel increasingly unsafe in their neighborhood even though this is not reflected in objective crime rates (Van Beckhoven et al., 2009). Or policy makers might label a neighborhood as a declining neighborhood even though this view is not shared by all residents. Therefore, policy definitions of decline do not always do justice to the lived experiences of residents.

It is important to notice that separating cause and effect in processes of neighborhood decline is extremely difficult, especially because processes of neighborhood decline are often set in motion by a chain reaction of a combination of social, economic or physical processes. Are, for example, technical problems with dwellings the result of decline because owners are not willing to invest in properties in a declining neighborhood, or are they the cause of decline because certain groups of residents leave neighborhoods with dwellings which are in a poor state of maintenance?

Finally, we find that the term neighborhood decline is often used in a very normative and stigmatizing way: is it fair to say that the inflow of low-income or ethnic minority groups equals neighborhood decline? Without joining the debate on segregation too much, we do raise some critical awareness about some of these often implicit assumptions. 


\section{The Geographies of the Economic Crisis}

Globalization implies that what happens in one country is increasingly affecting the situation in other countries. The financial market has become increasingly global, and this explains why the collapse of the sub-prime mortgage market and house price bubble in the United States has had repercussions on a global scale (Martin, 2011). Besides its major impact on the economy, the crisis has affected housing markets in different ways. First, the economic crisis has some predictable effects on the supply side of the housing market: in many countries, bank lending terms on mortgages tighten, the willingness of banks to lend money to prospective owners declines, investors in buildings become more selective, avoiding projects with too much risk, and regeneration and restructuring initiatives may be put on hold (Boelhouwer and Priemus, 2014; Raco and Tasan-Kok, 2009). Such developments lead to fewer possibilities of households to move, because the supply side of the housing market offers fewer opportunities. Second, the demand side of the housing market has changed. On both sides of the Atlantic, the financial crisis has led to high levels of unemployment, which left households unable to pay their mortgage and other debts. As many governments have cut spending because of extreme and quite sudden deficits, social safety nets and benefits are reduced, causing financial problems for low-income households. Often this leads to housing affordability problems: some may have to move to cheaper dwellings and less attractive neighborhoods, others have to stay put, because moving is too expensive or alternatives not available, or because negative equity makes it impossible for them to move.

Although the financial crisis has affected housing markets across the globe, which might suggest that geography does not matter much (Martin, 2011), different types of neighborhoods have experienced the crisis in different ways. Some neighborhoods might have experienced hardly any effects; in other neighborhoods income levels might have dropped because of in-situ changes such as rising unemployment; and again other neighborhoods might experience strongly declining housing values and a changing population composition. Despite arguments that increasing globalization makes the "local" less important and that people can go 'anywhere', the neighborhood is still important; the "degree of importance depends on who you are and where you are" (Forrest, 2000, p.30). We might add that it also depends on "when" you are: in times of crisis, (financial) limitations may make it more difficult for people to just "go" anywhere. While we have little insight in the effects of the crisis on the neighborhood level, it is likely that these effects differ between neighborhoods and residents, depending on several factors such as the quality of the existing housing stock, the status of local economies and the labor market, local incomes, opportunities for the creation of new dwellings and the population composition. As the unemployment rate rises most sharply amongst people with a low income and a low education, the effects of the crisis are likely to be felt the most in the most disadvantaged neighborhoods.

The economic crisis has fuelled the debate on neighborhood dynamics and this paper therefore calls for more research on the ways in which the crisis influences spatial patterns of increasing inequality.The aim of the present paper is to give an elaborate account of the literature on neighborhood decline with a special focus on the role of the economic crisis. Our goal is not to create the next all-encompassing model that explains neighborhood decline. Our aim is more modest: to make an inventory of the possible main effects of the global economic and financial crisis on neighborhood decline. In doing this, we take into account several factors and developments that have been identified by other authors, but we focus on their interrelations with economic developments. 


\section{The Role of the State and the Housing Market}

Differences in welfare state regimes are an important explanation for the wide range of differences in housing systems between countries. In countries where the government has historically been strongly involved in the development of affordable (social) housing, such as Denmark, Sweden and the Netherlands, the quality and the size of the social and public housing stock used to be high (Van Kempen and Priemus, 2002; Tsenkova and Turner, 2004; Teernstra and Van Gent, 2012). This relatively high quality has mitigated processes of neighborhood decline and has led to relatively low levels of income segregation in these countries. However, over the past few decades, severe cuts in housing subsidies took place in these countries and they have moved towards a more market-regulated housing system, where the responsibility for social housing shifted from public authorities to housing associations or social landlords. Housing associations are dependent on private funding to construct new social rented dwellings (Van Kempen and Priemus, 2002). The time that high-quality social housing is built by public authorities is over (e.g., Boelhouwer and Priemus, 2014).

The economic crisis has led to the implementation of many budget cuts and austerity programs that came on top of the cuts in housing subsidies that were implemented before the crisis. Together, these budget cuts have had an important impact on the opportunities for households on the housing market. Firstly, housing market access is largely determined by the financial position of households and governments play an important role in influencing the economic situation of households through income transfers or social security policies (cf. Lindbeck, 2006; Swank, 1998). Austerity programs and budget cuts directly affect the financial resources of households. Secondly, there have been substantial drops in house prices and housing construction has stagnated in many places (van der Heijden et al., 2011), although the effects have been less dramatic in countries with highly regulated housing finance systems, like Germany and Austria (Whitehead et al., 2014).

The declining production of affordable housing in combination with lower and more restrictive subsidies for renters limits their options to choose where to live. Financial restrictions force low-income groups to concentrate in neighborhoods where affordable housing options are still available. It can easily lead to increasing concentrations of lowincome groups in the worst areas.

\section{Hypothesis 1}

Austerity programs and budget cuts will lead to a smaller social safety net for vulnerable groups on the one hand, and to more limited options on the social housing market for lowincome groups on the other, leading to increasing concentrations of low-income groups in particular neighborhoods.

The extent of the impact of the crisis on the housing market depends on the volatility and structure of local and regional housing markets in different countries (van der Heijden et al., 2011). Over the past few decades, many countries have stimulated home-ownership because of the positive aspects associated with home-ownership (for overviews see Kleinhans, 2004; Kleinhans and van Ham, 2013). To encourage wealth accumulation through home-ownership, governments have made it possible for low to middle income groups and first-time buyers to obtain a mortgage. Because these groups were hit hardest by the economic crisis - interms of unemployment and declining incomes - theyare struggling the most with paying off their mortgages and are left with large debts in some cases. In the United States, sub-prime and predatory lending practices have disproportionally targeted disadvantaged groups in disadvantaged neighborhoods (Aalbers, 2009; Martin 2011). Sub-prime lending refers to the provision of mortgages at higher fees and interest rates, while predatory lending entails the 
imposition of excessive fees and interest rates (Aalbers, 2013). Many of these homeowners have seen the value of their homes drop during the crisis, and those who are unable to pay their mortgages are faced with displacement as the result of foreclosures. Often, a high rate of foreclosures in a neighborhood is associated with neighborhood decline because of increasing crime rates (Newman, 2009; Ojeda, 2009; Martin, 2011). In the US, this leads to strong spillover effects of housing values, crime and neighborhood decline on surrounding areas, making it extremely difficult for sitting residents to refinance or sell their properties (Immergluck, 2009; Lardner, 2008; Newman, 2009; Aalbers, 2009; Martin, 2011).

\section{Hypothesis 2}

The effects of the crisis on neighborhoods are stronger in those countries that have actively stimulated home-ownership. Especially neighborhoods with an overrepresentation of low to middle income households and first-time buyers will be affected by processes of decline.

In countries where there was a deliberate policy to expand home-ownership prior to the crisis, it will be more difficult for low to middle income groups and first-time buyers to obtain a mortgage than in the past (Boelhouwer and Priemus, 2014; Clark, 2013).It is likely that the mortgage finance market will be reformed to ensure the affordability and creditworthiness of households and individuals and reduce the hereto related defaults risks (Martin, 2011). Mortgage securitization then ultimately means that particular groups and areas are excluded from the mortgage housing market (ibid). When mortgages are only provided to high-income groups in specific areas, low to middle income groups are forced to turn to the rental sector that is often concentrated in particular areas.

\section{Hypothesis 3}

Mortgage market reforms are likely to exclude low to middle income groups and first-time buyers, creating a large group in need of affordable housing. At the same time, mortgage market reforms will lead to declining home-ownership in particular areas, creating a spatial divide based on different tenures.

\section{Urban Renewal}

Over the past decades, many European countries, such as the United Kingdom, Sweden, Denmark and the Netherlands, have implemented neighborhood regeneration programs. The general goal of these programs was to reduce the relative inequality between the most disadvantaged neighborhoods and the city or national average (Jivraj, 2012). The ways in which these urban renewal programs are pursued in practice differs between countries (Skifter Andersen, 1999; Van Gent, 2010). However, in most countries policies were implemented to improve the situation in deprived neighborhoods through housing diversification. Examples are HOPE VI in the United States, the Urban Restructuring Program in the Netherlands and the New Deal for Communities in the United Kingdom (e.g., Goetz, 2010; Bolt and Van Kempen, 2011; Phillips and Harrison, 2010).

It is believed by many policy makers that the mixing of different socioeconomic groups in disadvantaged areas will lead to neighborhood upgrading (Andersson and Musterd, 2005; Van Gent et al., 2009). In many cases, urban regeneration implied the demolition of low cost rental dwellings, and often (but not always) low-quality dwellings, replacing them by more upmarket owner-occupied and expensive rental dwellings. In this way, spatial concentrations of low cost rental dwellings were broken up, and, consequently, concentrations of low-income households were dispersed over the rest of the city or the urban region. The 
original residents of the demolished dwellings were forced to relocate to other (often nearby, often also disadvantaged) neighborhoods where affordable housing was still available (Crump, 2002; Van Kempen and Priemus, 2002; Bolt et al., 2008; Posthumus et al., 2013), as these residents did not have the means to move to the more expensive newly created housing in the regeneration area (Kleinhans and Varady, 2011). It has thus been argued that regeneration programs may lead to the downgrading of other (surrounding) neighborhoods, because the previous spatially concentrated deprivation becomes dispersed over a larger geographical area (Andersson et al., 2010; Brama, 2013; Posthumus et al., 2013).

While these mixing policies can be successful in improving the statistics of a neighborhood significantly, most of these policies have, however, been heavily criticized for failing to really improve the lives of the original residents (Goetz, 2010; Van Ham and Manley, 2012). Nevertheless, such programs are often seen as successful by policy makers, and it is fair to say that these programs have contributed to decreasing segregation to at least some extent (Musterd and Ostendorf, 2005). An argument that is often put forward is that countries such as the Netherlands and Sweden do not have ghetto-like neighborhoods because of a strong government involvement and mixing policies. This raises the question whether the retreat of these governments as a result of the economic crisis will fuel a process of socioeconomic segregation and neighborhood decline. To what extent these neighborhoods will be subject to rapid processes of neighborhood decline will depend on the long-term effects of urban renewal programs (see also Tunstall, this issue).

\section{Hypothesis 4}

The crisis will contribute most to processes of neighborhood decline and segregation in those countries with the strongest tradition of neighborhood renewal and mixing. The retreat of the government from the housing market, combined with budget cuts and austerity programs, will fuel neighborhood decline in those areas where government involvement functioned as a mitigating factor.

Besides urban renewal programs, another policy measure to improve the position of a neighborhood and its households has been to sell rental dwellings to sitting tenants or to new inhabitants when the rental dwellings became vacant. Research has shown that the sales of social housing hardly contribute to neighborhood upgrading and/or stability (see Kleinhans and Van Ham, 2013). Instead, selling off part of the (social or public) rental stock has been associated with residualization of social housing: because those with higher incomes, and those living in the better dwellings and neighborhoods are most likely to buy their dwellings, the remaining social housing stock will be of relatively low quality and home to lower income households (Forrest and Murie, 1983; Kleinhans and Van Ham, 2013). Thus, the effect of selling stock is often a larger concentration of low-income households in the worst parts of the rented stock (Meusen and Van Kempen, 1995). When these dwellings are spatially clustered, selling stock is a clear recipe for neighborhood decline.

In times of crisis, it becomes more difficult to sell rental dwellings. Mainly low to middle income groups were targeted for the sales of rental dwellings, and, as we have argued before, it becomes increasingly difficult for these groups to obtain a mortgage. Reducing the sales of rental dwellings stabilizes the process of residualization of the social housing stock to some extent, however, at the same time, it widens the gap between rental and owner-occupied dwellings. The sales of rented properties for relatively low prices made it possible for many low to middle income group to become home-owners. As this becomes increasingly difficult, affordable low to middle-cost owner-occupied dwellings are likely to more scarce. 


\section{Hypothesis 5}

The economic crisis slows down the sales of social rented dwellings. This will stabilize the process of residualization of the social housing stock and social housing estates.

\section{The Starting Position, Social Cohesion and Residential Mobility}

In the previous sections we discussed several exogenous factors that can fuel or mitigate neighborhood decline, like the state of the economy, the involvement of the state in the housing market and urban renewal. At the same time internal factors also play a role in neighborhood decline. The initial technical quality of dwellings and neighborhoods forms an important material basis for the explanation of neighborhood decline. Some authors take an almost deterministic stance regarding the relevance of this "hard" variable (e.g., Newman, 1972; Coleman, 1985; and to a lesser extent Power, 1997).Recent research by Meen and colleagues (2013) has emphasized the relevance of this aspect and has shown how some areas maintain their high-quality status and position in the neighborhood hierarchy for a long time. They argue that some areas have always had a natural advantage over others because of their location and/or access to particular resources, such as a proximity to ports or transportation centers, or fertile soil. These advantages are then reinforced over time (Meen et al., 2013; Meen and Nygaard, 2011), similar to the reputation of a neighborhood (whether it is good or bad) that turns out to be sticky in the course of time (Sampson, 2009; Tunstall, 2015). The initial quality of a neighborhood is also influenced by the (dominant) housing type. Especially neighborhoods with post-war high-rise residential buildings are prone to processes of neighborhood decline through thelow quality of, and technical problems with, these buildings (e.g. Kleinhans, 2004; Dekker and Van Kempen, 2004; Van Beckhoven et al., 2009; Kearns, 2012).

The importance of the initial quality of dwellings and neighborhoods was first recognized by Prak and Priemus in 1986. They created a theoretical model of neighborhood decline that mainly concentrated on the Dutch/European situation of post-WWII social housing. In their model, they argue that the low quality of dwellings combined with several technical problems led to different (economic, social, technical) spirals of decline. Fuelled by increasing residential mobility; (social) landlords are faced with declining profits because of the outflow of middle- and higher-income groups and the inflow of low-income households. At the same time, higher turnover rates, residential problems and increasing maintenance costs to keep complexes attractive, will result in higher costs.

Especially in times of economic crisis, when financial resources are scarce, landlords and housing associations may reduce investment or maintenance costs (decreasing the quality of the housing stock further), leading to further decline. In times of crisis, it may thus be expected that the general picture described above will be reinforced in especially post-war neighborhoods. However, Turkington et al. (2004) and Musterd et al. (2009) have argued that, from an international perspective, it is important to realize that not all post-WWII mass housing estates in Europe are the same. Although such estates may at first sight all look alike, a deeper analysis indicates that some buildings and areas are much worse off than others, depending on the level of maintenance and investments. Moreover, in many countries these post-war neighborhoods were targeted for large-scale urban renewal programs. While the most disadvantaged estates were demolished or renovated, the overall share of post-war housing remained high in these neighborhoods (Dol and Kleinhans, 2012). 


\section{Hypothesis 6}

The negative effects of the crisis are likely to be stronger in those areas that are characterized by an initial low quality; depending on the level of maintenance and investments, and the extent of urban restructuring in the past.

Declining housing and neighborhood quality can spur residential mobility: middle- and higher-income groups are moving out as a result of the decreasing attraction of dwellings and neighborhoods and the creation of new dwellings elsewhere, a process also known as relative depreciation (see also Grigsby et al., 1987). Neighborhoods can change rapidly as a result of selective mobility where the socio-economic and demographic characteristics of those households leaving are different from the characteristics of the newly arrived households. The likelihood of a household moving depends on whether preferences of households can be realized by the resources available to the household within the opportunities (available dwellings) and restrictions (ability to get a mortgage) of the desired housing market (Clark and Dieleman, 1996; Mulder and Hooimeijer,1999). Generally speaking, more affluent households have a larger choice set of houses and neighborhoods.

The economic crisis is likely to have major impacts on residential mobility. On the one hand, we have argued that people tend to be more limited in their options due to financial restrictions and changes on the housing market. Households might want to move, but are not able to move because they cannot get a mortgage, or because they cannot sell their current home without making a large financial loss. It has been argued that also higher-income households are less able to move in times of economic crisis (Dwyer, 2007; Aalbers, 2013). This may in fact impede further socioeconomic segregation.

\section{Hypothesis 7}

The economic crisis leaves a large group of households immobile. Financial constraints combined with increasing restrictions on the supply side of the housing market forces people to stay in their dwelling and neighborhood, slowing down processes of segregation due to, for example, a lower level of suburbanization of the middle classes from the city.

Another possibility is that households have to leave their homes because they cannot afford their homes anymore. Households who despite the crisis are still able to move might want to take advantage of lower house prices and leave undesirable neighborhoods. If they are unable to sell their dwelling, they often decide to keep the dwelling and to rent it out privately, leading to high turnover rates combined with the facilitation of access to low income tenants (Kleinhans and van Ham, 2013).When they are able to sell the dwelling, they are likely to be replaced by lower income households. On the other hand, the crisis has also led to more vacancies in neighborhoods that are most hit by the foreclosure crisis (Hyra and Rugh, 2015). In the USA, these neighborhoods are often characterized by a high poverty rate and high proportion of black households. The high rate of vacancies in these areas are depressing property values and increases the risk of deterioration, social disorganization and crime (Ellen et al., 2014).

\section{Hypothesis 8}

In times of crisis, residential mobility is likely to lead to further neighborhood decline because of an increasing vacancy rate, and because of selective migration, leading to the inflow of lower income households.

According to Prak and Priemus (1986), high rates of residential mobility will lead to a breakdown of the social fabric, causing more and more crime-related problems, making an 
area even less attractive for middle- and higher-income groups (see also Varady, 1986; Prak and Priemus, 1986; Temkin and Rohe, 1996; Van Beckhoven et al., 2009). It is often assumed that disadvantaged neighborhoods particularly suffer from the lack of strong social ties and the advantages that they bring along (Forrest and Kearns, 2001).Without a strong social fabric, neighborhoods are more prone to disorder in terms of vandalism; nuisance and crime (Kleinhans and Bolt, 2014). The social disorganization theory, which originated from the Chicago School of Sociology, stated that disorganization in neighborhoods is caused by incapability of the local community in terms of a lack of (access) to resources, residential instability, or a weak social network (Shaw and McKay, 1942). Physical and social problems arise because residents are not able to enforce certain norms and to maintain social control. As a result, governments tend to retreat from public space and residents lose their trust in each other and 'hunker down' (Ross et al., 2001; Putnam, 2007). Some researchers have argued that small levels of disorder (such as graffiti or broken windows) give rise to more serious crime offenses (Wilson and Kelling, 1982). This broken windows theory states that potential criminals interpret these levels of disorder as a sign of a lack of social control or involvement of the residents, and as such, feel free to engage in criminal behavior.

In times of crisis, the social cohesion in (disadvantaged) neighborhoods can develop in different directions. With many governments retreating, more and more responsibility for the neighborhoods has shifted to its residents. In neighborhoods where many residents are unable to move, people may find each other because of a common fate, actually increasing social cohesion in these areas. It can lead to a strengthening of networks of solidarity and a deepening attachment to place, even in very stigmatized areas like the French banlieues (Kirkness, 2014). However, it is also possible that those neighborhoods that are experiencing an inflow of lower-income groups are prone to increasing social disorganization. A change of population composition might lead to residential stress as people tend to prefer a neighborhood population that matches their own characteristics. In other words, they do not want to be part of a minority population in their neighborhood (Feijten and Van Ham, 2009; McPherson et al., 2001). If that stress cannot be solved by moving to a neighborhood that better meets the demand to live amongst similar people, it may lead to tensions.

\section{Hypothesis 9}

In times of crisis, social cohesion may be reinforced in areas where there has been a reasonable level of social interaction in the past, while it is likely to crumble down in areas that experience increasing tensions because of a diversification of the population composition.

Demographic processes are an important explanation of how neighborhoods can experience (population) change without residential migration. More and more studies are arguing that this so-called in-situ change can be a stronger driver of neighborhood change than selective residential migration (Bailey, 2012; Cooke, 2010; Rosenbaum, 1995; Strait, 2006; Coulton et al., 2012: Teernstra, 2014; Jivraj, 2013). Finney (2013) has, for example, argued that ethnic concentrations in a neighborhood can increase without any residential migration. The young age structure of many ethnic groups and their relatively high fertility rates, combined with high mortality rates among older native groups, will increase the share of ethnic minorities in particular neighborhoods.

How does the economic crisis further affect such demographic processes and consequently neighborhood change? For Western countries, it is difficult to make direct relations between economic developments on the one hand and mortality and fertility on the other hand. Declining incomes may lead to postponing the wish to have children, but it is unclear if this differs between socioeconomic or ethnic groups. Declining incomes may also 
lead to health problems and possibly higher mortality, but it is unclear whether this would have an effect on neighborhoods. When residential mobility declines as a consequence of the economic crisis (see above), incumbent processes may become relatively more important in explaining changes in a neighborhood. Poor neighborhoods are most likely to be hit by increasing unemployment and declining incomes (Andersson and Hedman, 2015). Older children of poor households may have fewer opportunities to find an independent home and stay longer with their parents, especially if these children cannot find a paid job. This might again increase the poverty level of an area.

\section{Hypothesis 10}

When residential mobility decreases as a result of the crisis, incumbent processes become more important in explaining neighborhood change.

\section{Conclusions}

In this paper, we have argued that neighborhood decline is a multidimensional process that can be explained by both exogenous and endogenous factors on different levels. The interaction of different factors on the micro- and macro-level heavily depends on the context in space and time. There is a lack of empirical studies that have focused on the effects of the crisis on neighborhoods and their residents. In an attempt to push the debate forward, we have formulated ten hypotheses on ways in which the economic crisis might interact with processes of neighborhood decline. Research in this field is necessary because thedifferences in the local effects of the crisis are likely to lead to a widening of the gap between wealthy and disadvantaged neighborhoods. In combination with severe budget-cuts and the implementation of austerity programs, this raises concerns about increasing spatial segregation in the near future. There is a need for a more stable mortgage finance market and several reforms have been suggested to ensure the accountability and creditworthiness of households and create more mortgage securitization (Bair, 2008; Martin, 2011). This implies that it will be much more difficult for low- to middle-income households to get a mortgage and pursue homeownership, meaning that there is a need for a larger affordable (social) rented sector.

In this article, we have identified several factors from the literature that influence neighborhood change. However, we are realizing how little we actually know about the ways in which these factors interact in different contexts. This article therefore calls for more longitudinal research of neighborhoods and households that focuses on the drivers of neighborhood decline, and more generally, neighborhood change. Without longitudinal data on the residential and social mobility of households, it is not possible to disentangle the relative weight of residential sorting and incumbent processes in explaining neighborhood change. This is not only an academic question, but also relevant in the evaluation of neighborhood regeneration programs. Do we, for instance, see an improvement in the livability and social status of neighborhood due to the empowerment of the existing population or due to the replacement of vulnerable groups by middle class households?

Most studies that focus on neighborhood change tend to concentrate on case-studies of specific cities, or specific gentrifying or declining neighborhoods. This lack of knowledge can be largely attributed to the complexity of the subject, a lack of (comparable) longitudinal data and a bulk of statistical problems with which researchers are confronted; it nevertheless constitutes a large gap in our understanding of neighborhood dynamics. Neighborhoods do not operate in a vacuum and while a particular neighborhood may experience absolute change, the picture may be completely different when we look at the relative change in a city or a country. Moreover, in a globalizing world, with growing internationally connected 
economies and housing markets, it will become increasingly important to understand neighborhood change from a more global perspective.

The financial crisis has had different economic, physical, social and health-related outcomes, most of which we are only now beginning to grasp. Researchers have argued that the crisis has had different local outcomes between and within countries (Aalbers, 2009). We have very little insight in the long-term effects of the crisis on neighborhoods and its residents. It is important to understand how the crisis has affected spatial patterns of increasing inequality, and as such different neighborhood trajectories. A deeper understanding of the drivers behind neighborhood decline can contribute to the development of effective policy-making in the aftermath of the economic crisis.

\section{Acknowledgements}

The research leading to these results has received funding from Platform31 in the Netherlands; from the European Research Council under the European Union's Seventh Framework Programme (FP/2007-2013) / ERC Grant Agreement n. 615159 (ERC Consolidator Grant DEPRIVEDHOODS, Socio-spatial inequality, deprived neighbourhoods, and neighbourhood effects); and from the Marie Curie programme under the European Union's Seventh Framework Programme (FP/2007-2013) / Career Integration Grant n. PCIG10-GA-2011-303728 (CIG Grant NBHCHOICE, Neighbourhood choice, neighbourhood sorting, and neighbourhood effects).

\section{REFERENCES}

Aalbers, Manuel, B. (2009). Geographies of the Financial Crisis. Area, 41(1), 34-42.

Aalbers, Manuel, B. (2013). How do Mortgage Lenders influence Neighbourhood Dynamics? Redlining and Predatory Lending. In Maarten van Ham, David Manley, Nick Bailey, Ludi Simpson and Duncan MacLennan, editors, Understanding Neighbourhood Dynamics: New Insights for Neighbourhood Effects Research. Dordrecht, the Netherlands: Springer, 63-85.

Andersson, Roger, Bråmå, Åsa, and Holmqvist, Emma. (2010). Counteracting Segregation: Swedish Policies and Experiences. Housing Studies, 25(2), 237-256.

Andersson, Roger, and Hedman, Lina. (2015). Economic Decline and Residential Segregation: A Swedish Study with Focus on Malmö. Urban Geography, (forthcoming).

Andersson, Roger, and Musterd, Sako. (2005). Area-Based Policies: A Critical Appraisal. Tijdschrift voor Economische en Sociale Geografie, 96(4), 377-389.

Bailey, Nick. (2012). How Spatial Segregation Changes over Time: Sorting out the Sorting Processes. Environment and Planning A, 44(3), 705-722.

Bair, Sheila C. (2008). Reforming Mortgage Finance. Business Economics, 43(4), 13-16.

Bellmann, Lutz, and Gerner, Hans-Dieter. (2011). Reversed Roles? Wage and Employment Effects of the Current Crisis. In Herwig Immervoll, Andreas Peichl, and Konstantinos Tatsiramos, editors, Who Loses in the Downturn? Economic Crisis, Employment and Income Distribution (Research in Labor Economics, Volume 32). Bingley, United Kingdom: Emerald Group Publishing Limited, 181-206.

Boelhouwer, Peter, and Priemus, Hugo. (2014). Demise of the Dutch Social Housing Tradition: Impact of Budget Cuts and Political Changes. Journal of Housing and the Built Environment, 29(2), 221-235. 
Bolster, Anne, Burgess, Simon, Johnston, Ron, Jones, Kelvyn, Propper, Carol, and Sarker, Rebecca. (2007). Neighbourhoods, Households and Income Dynamics: A SemiParametric Investigation of Neighbourhood Effects. Journal of Economic Geography, 7(1), 1-38.

Bolt, Gideon, and Van Kempen, Ronald. (2011). Successful Mixing? Effects of Urban Restructuring Policies in Dutch Neighbourhoods. Tijdschrift voor Economische en Sociale Geografie, 102(3), 361-368.

Bolt, Gideon, Van Kempen, Ronald, and Van Ham, Maarten. (2008). Minority Ethnic Groups in the Dutch Housing Market: Spatial Segregation, Relocation Dynamics and Housing Policy. Urban Studies, 45(7), 1359-1384.

Bråmå, Åsa. (2013). The Effects of Neighbourhood Regeneration on the Neighbourhood Hierarchy of the City: A Case Study in Sweden. In Maarten van Ham, David Manley, Nick Bailey, Ludi Simpson, and Duncan Maclennan, editors, Understanding Neighbourhood Dynamics: New Insights for Neighbourhood Effects Research. Dordrecht, the Netherlands: Springer, 111-138.

Cheshire, Paul C. (2007). Segregated Neighbourhoods and Mixed Communities: A Critical Analysis. York, United Kingdom: Joseph Rowntree Foundation.

Clark, William A.V. (2013). The Aftermath of the General Financial Crisis for the Ownership Society: What Happened to Low-Income Homeowners in the US? International Journal of Housing Policy, 13(3), 227-246.

Clark, William A.V., and Dieleman, Frans M. (1996). Households and Housing: Choice and Outcomes in the Housing Market. New Brunswick, NJ: Centre for Urban Policy Research.

Coleman, Alice. (1985). Utopia on Trial: Vision and Reality in Planned Housing: London, United Kingdom: Shipman.

Cooke, Thomas J. (2010). Residential Mobility of the Poor and the Growth of Poverty in Inner-Ring Suburbs. Urban Geography, 31(2), 179-193.

Coulton, Claudia, Theodos, Brett, and Turner, Margery A. (2012). Residential Mobility and Neighborhood Change: Real Neighborhoods Under the Microscope. Cityscape, 14(3), 55-89.

Crump, Jeff. (2002). Deconcentration by Demolition: Public Housing, Poverty, and Urban Policy. Environment and Planning D, 20(5), 581-596.

Dekker, Karien, and Van Kempen, Ronald. (2004). Large Housing Estates in Europe: Current Situation and Developments. Tijdschrift voor Economische en Sociale Geografie, 95(5), 570-577.

Dol, Kees, and Kleinhans, Reinout. (2012). Going too Far in the Battle Against Concentration? On the Balance between Supply and Demand of Social Housing in Dutch Cities. Urban Research \& Practice, 5(2), 273-283.

Doucet, Brian. (2014). A Process of Change and a Changing Process: Introduction to the Special Issue on Contemporary Gentrification. Tijdschrift voor Economische en Sociale Geografie, 105(2), 125-139.

Downs, Anthony. (1981). Neighborhoods and Urban Development: Washington, DC: Brookings Institution Press.

Dwyer, Rachel E. (2007). Expanding Homes and Increasing Inequalities: USHousing Development and the Residential Segregation of the Affluent. Social Problems, 54(1), 23-46.

Ellen, Ingrid Gould, Madar, Josiah, andWeselcouch, Mary. (2014). The Foreclosure Crisis and Community Development: Exploring REO Dynamics in Hard-Hit Neighborhoods. Housing Studies (ahead-of-print), 1-25. 
European Commission. (2010). The European Platform against Poverty and Social Exclusion. A European Framework for Social and Territorial Cohesion. SEC(2010), 1564final. Brussels.

Feijten, Peteke, and Van Ham, Maarten. (2009). Neighbourhood Change... Reason to Leave? Urban Studies, 46(10), 2103-2122.

Finney, Nissa. (2013). How Ethnic Mix Changes: Typologising Neighbourhood Population Dynamics of Ethnic Groups. In Maarten van Ham, David Manley, Nick Bailey, Ludi Simpson, Duncan Maclennan, editors, Understanding Neighbourhood Dynamics: New Insights for Neighbourhood Effects Research. Dordrecht, the Netherlands: Springer, 203-224.

Forrest, Ray. (2000). Does Neighbourhood Still Matter in a Globalised World? Occasional Paper Series No 5. Hong Kong, Japan: Centre for Comparative Public Management and Social Policy, City University of Hong Kong.

Forrest, Ray, and Kearns, Ade. (2001). Social Cohesion, Social Capital and the Neighbourhood. Urban Studies, 38(12), 2125-2143.

Forrest, Ray, and Murie, Alan. (1983). Residualization and Council Housing: Aspects of the Changing Social Relations of Housing Tenure. Journal of Social Policy, 12(4), 453468.

Galster, George. (2001). On the Nature of Neighbourhood. Urban Studies, 38(12), 2111-2124.

Galster, George. (2012). The Mechanism(s) of Neighbourhood Effects: Theory, Evidence, and Policy Implications. In Maarten van Ham, David Manley, Nick Bailey, Ludi Simpson, and Duncan Maclennan, editors, Neighbourhood Effects Research: New Perspectives. Dordrecht, the Netherlands: Springer, 23-56.

Gili, Margalida, Roca, Miquel, Basu, Sanjay, McKee, Martin, and Stuckler, David. (2013). The Mental Health Risks of Economic Crisis in Spain: Evidence from Primary Care Centres, 2006 and 2010. The European Journal of Public Health, 23(1), 103-108.

Goetz, Edward G. (2010). Desegregation in 3D: Displacement, Dispersal and Development in American Public Housing. Housing Studies, 25(2), 137-158.

Grigsby, William, Baratz, Morton, Galster, George, and Maclennan, Duncan. (1987). The Dynamics of Neighborhood Change and Decline. Progress in Planning, 28(1), 1-76.

Hyra, Derek and Rugh, Jacob. (2015). The US Great Recession: Exploring Its Association with Black Neighborhood Rise, Decline and Recovery. Urban Geography, (forthcoming).

Immergluck, Dan. (2009). Re-forming Mortgage Markets: Sound and Affordable Home Lending in a New Era. Ithaca, NY: Cornell University Press.

Immervoll, Herwig, Peichl, Andreas, and Tatsiramos, Konstantinos. (2011). Who Loses in the Downturn? Economic Crisis, Employment and Income Distribution (Research in Labor Economics, Volume 32). Bingley, United Kingdom: Emerald Group Publishing Limited.

Jivraj, Stephen. (2012). Modelling Socioeconomic Neighbourhood Change due to Internal Migration in England. Urban Studies, 49(16), 3565-3578.

Jivraj, Stephen. (2013). The Components of Socioeconomic Neighbourhood Change: An Analysis of School Census Data at Varying Spatial Scales in England. In Maarten van Ham, David Manley, Nick Bailey, Ludi Simpson, Duncan Maclennan, editors, Understanding Neighbourhood Dynamics: New Insights for Neighbourhood Effects Research. Dordrecht, the Netherlands: Springer, 183-201.

Kearns, Ade, Whitley, Elise, Mason, Phil, and Bond, Lyndal. (2012). 'Living the High Life'? Residential, Social and Psychosocial Outcomes for High-Rise Occupants in a Deprived Context. Housing Studies, 27(1), 97-126. 
Kirkness, Paul. (2014). The Cités Strike Back: Restive Responses to Territorial Taint in the French Banlieues. Environment and Planning A, 46(6), 1281-1296.

Kleinhans, Reinout, and van Ham, Maarten. (2013). Lessons Learned from the Largest Tenure-Mix Operation in the World: Right to Buy in the United Kingdom. Cityscape, 15(2), 101-117.

Kleinhans, Reinout, and Varady, David. (2011). Moving Out and Going Down? A Review of Recent Evidence on Negative Spillover Effects of Housing Restructuring Programmes in the United States and the Netherlands. International Journal of Housing Policy, 11(2), 155-174.

Kleinhans, Reinout J. (2004). Social Implications of Housing Diversification in Urban Renewal: A Review of Recent Literature. Journal of Housing and the Built Environment, 19(4), 367-390.

Kleinhans, Reinout J., and Bolt, Gideon. (2014). More Than Just Fear: On the Intricate Interplay Between Perceived Neighborhood Disorder, Collective Efficacy, and Action. Journal of Urban Affairs, 36(3), 420-446.

Lardner, James. (2008). Beyond the Mortgage Meltdown: Addressing the Current Crisis, Avoiding a Future Catastrophe. Washington, DC: Dēmos.

Lees, Loretta. (2008). Gentrification and Social Mixing: Towards an Inclusive Urban Renaissance? Urban Studies, 45(12), 2449-2470.

Lindbeck, Assar. (2006). The Welfare State. Background, Achievements, Problems. Stockholm, Sweden: IUI, The Research Institute of Industrial Economics.

Martin, Ron. (2011). The Local Geographies of the Financial Crisis: From the Housing Bubble to Economic Recession and Beyond. Journal of Economic Geography, 11(4), 587-618.

McPherson, Miller, Smith-Lovin, Lynn, and Cook, James M. (2001). Birds of a Feather: Homophily in Social Networks. Annual Review of Sociology, 27(1), 415-444.

Meen, Geoffrey, and Nygaard, Christian. (2011). Local Housing Supply and the Impact of History and Geography. Urban Studies, 48(14), 3107-3124.

Meen, Geoffrey, Nygaard, Christian, and Meen, Julia. (2013). The Causes of Long-Term Neighbourhood Change. In Maarten van Ham, David Manley, Nick Bailey, Ludi Simpson \& Duncan Maclennan, editors, Understanding Neighbourhood Dynamics: New Insights for Neighbourhood Effects Research. Dordrecht, the Netherlands: Springer, 43-62.

Meusen, Hans, and Van Kempen, Ronald. (1995). Towards Residual Housing? A Comparison of Britain and the Netherlands. Journal of Housing and the Built Environment, 10(3), 239-258.

Morris, David, and Hess, Karl. (1975). Neighborhood Power: The New Localism. Boston, MA: Beacon Press.

Mulder, Clara H, and Hooimeijer, Pieter. (1999). Residential Relocations in the Life Course. In Leo van Wissen and Pearl Dykstra, editors, Population Issues: An Interdisciplinary Focus. Den Haag, the Netherlands: NIDI, 159-186.

Musterd, Sako, and Ostendorf, Wim. (2005). Social Exclusion, Segregation, and Neighbourhood Effects. In Yuri Kazepov, editor, Cities of Europe: Changing Contexts, Local Arrangements and the Challenge to Urban Cohesion. Oxford, UK: Blackwell, 170189.

Musterd, Sako, Van Kempen, Ronald, and Rowlands, Rob. (2009). Mass Housing Estates on Different Tracks: An Introduction to the Book. In Rob Rowlands, Sako Musterd, and Ronald van Kempen, editors, Mass Housing in Europe: Multiple Faces of Development, Change and Response. Basingstoke, United Kingdom: Palgrave Macmillan, 1-19. 
Newman, Kathe. (2009). Post-Industrial Widgets: Capital Flows and the Production of the Urban. International Journal of Urban and Regional Research, 33(2), 314-331.

Newman, Oscar. (1972). Defensible Space. New York, NY: Macmillan.

OECD. (2013). Crisis squeezes income and puts pressure on inequality and poverty. Retrieved from www.oecd.org/social/inequality.htm

OECD. (2014). Society at a Glance 2014: OECD Social Indicators, OECD Publishing.

Ojeda, Raul H. (2009). The Continuing Home Foreclosure Tsunami: Disproportionate Impacts on Black and Latino Communities. WCVI White Paper, San Antonio, TX: William C. Velasquez Institute.

Oreopoulos, Philip. (2003). The Long-Run Consequences of Living in a Poor Neighborhood. The Quarterly Journal of Economics, 118(4), 1533-1575.

Phillips, Deborah, and Harrison, Malcolm. (2010). Constructing an Integrated Society: Historical Lessons for Tackling Black and Minority Ethnic Housing Segregation in Britain. Housing Studies, 25(2), 221-235.

Posthumus, Hanneke, Bolt, Gideon, and Van Kempen, Ronald. (2013). Why do Displaced Residents Move to Socioeconomically Disadvantaged Neighbourhoods? Housing Studies, 28(2), 272-293.

Power, Anne. (1997). Estates on the Edge: The Social Construction of Mass Housing in Northern Europe. London, United Kingdom: Macmillan.

Prak, Niels L., and Priemus, Hugo. (1986). A Model for the Analysis of the Decline of Postwar Housing. International Journal of Urban and Regional Research, 10(1), 1-7.

Priemus, Hugo, and Dieleman, Frans. (2002). Social Housing Policy in the European Union: Past, Present and Perspectives. Urban Studies, 39(2), 191-200.

Putnam, Robert D. (2007). E Pluribus Unum: Diversity and Community in the Twenty-First Century. The 2006 Johan Skytte Prize Lecture. Scandinavian Political Studies, 30(2), 137-174.

Raco, Mike, and Tasan-Kok, Tuna. (2009). Competitiveness, Cohesion, and the Credit Crunch: Reflections on the Sustainability of Urban Policy. In Katrien de Boyser, Caroline Dewilde, Danielle Dierckx, and JürgenFriedrichs, editors, Between the Social and the Spatial: Exploring the Multiple Dimensions of Poverty and Social Exclusion. Farnham, United Kingdom: Ashgate, 183-195.

Rosenbaum, Emily. (1995). The Making of a Ghetto: Spatially Concentrated Poverty in New York City in the 1980s. Population Research and Policy Review, 14(1), 1-27.

Ross, Catherine E, Mirowsky, John, and Pribesh, Shana. (2001). Powerlessness and the Amplification of Threat: Neighborhood Disadvantage, Disorder, and Mistrust. American Sociological Review, 66, 568-591.

Sampson, Robert J. (2009). Disparity and Diversity in the Contemporary City: Social (Dis)order Revisited. The British Journal of Sociology, 60(1), 1-31.

Sampson, Robert J., Morenoff, Jeffrey D., and Gannon-Rowley, Thomas. (2002). Assessing "Neighborhood effects": Social Processes and New Directions in Research. Annual Review of Sociology, 28, 443-478.

Schoenberg, Sandra P. (1979). Criteria for the Evaluation of Neighborhood Viability in Working Class and Low Income Areas in Core Cities. Social Problems, 27(1), 69-78.

Shaw, Clifford R., and McKay, Henry D. (1942). Juvenile Delinquency and Urban Areas. Chicago, IL: University of Chicago Press.

Skifter Andersen, Hans. (1999). Housing Rehabilitation and Urban Renewal in Europe: A Cross-National Analysis of Problems and Policies. In Hans Skifter Andersen and Philip Leather, editors, Housing Renewal in Europe. Bristol, United Kingdom: The Policy Press, 241-277. 
Strait, John B. (2006). Poverty Concentration in the Prismatic Metropolis: The Impact of Compositional and Redistributive Forces within Los Angeles, California, 1990-2000. Journal of Urban Affairs, 28(1), 71-94.

Swank, Duane. (1998). Funding the Welfare State: Globalization and the Taxation of Business in Advanced Market Economies. Political Studies, 46(4), 671-692.

Teernstra, Annalies. (2014). Neighbourhood Change, Mobility and Incumbent Processes: Exploring Income Developments of In-Migrants, Out-Migrants and Non-Migrants of Neighbourhoods. Urban Studies, 51(5), 978-999.

Teernstra, Annalies, and Van Gent, Wouter P.C. (2012). Puzzling Patterns in Neighborhood Change: Upgrading and Downgrading in Highly Regulated Urban Housing Markets. Urban Geography, 33(1), 91-119.

Temkin, Kenneth, and Rohe, William. (1996). Neighborhood Change and Urban Policy. Journal of Planning Education and Research, 15(3), 159-170.

Tsenkova, Sasha, and Turner, Bengt. (2004). The Future of Social Housing in Eastern Europe: Reforms in Latvia and Ukraine. European Journal of Housing Policy, 4(2), 133-149.

Tunstall, Rebecca. (2015). Are Neighbourhoods Dynamic or are they Slothful? The Limited Prevalence and Extent of Change in Neighbourhood Socio-Economic Status, and its Implications for Regeneration Policy. Urban Geography, (forthcoming).

Turkington, Richard, Van Kempen, Ronald, and Wassenberg, Frank. (2004). High-Rise Housing in Europe: Current Trends and Future Prospects. Delft, the Netherlands: Delft University Press.

Van Beckhoven, Ellen, Bolt, Gideon, and Van Kempen, Ronald. (2009). Theories of Neighbourhood Change and Neighbourhood Decline: Their Signficance for PostWWII Large Housing Estates. In Sako Musterd, Ronald van Kempen and Rob Rowlands, editors, Mass Housing in Europe: Multiple Faces of Development, Change and Response. Basingstoke, United Kingdom: Palgrave MacMillan, 20-50.

Van der Heijden, Harry, Dol, Kees, and Oxley, Michael. (2011). Western European Housing Systems and the Impact of the International Financial Crisis. Journal of Housing and the Built Environment, 26(3), 295-313.

Van Gent, Wouter P.C. (2010). Housing Context and Social Transformation Strategies in Neighbourhood Regeneration in Western European cities. International Journal of Housing Policy, 10(1), 63-87.

Van Gent, Wouter P.C., Musterd, Sako, and Ostendorf, Wim. (2009). Bridging the Social Divide? Reflections on Current Dutch Neighbourhood Policy. Journal of Housing and the Built Environment, 24(3), 357-368.

Van Ham, Maarten., Hedman, Lina, Manley, David, and Östh, John. (2014). Intergenerational Transmission of Neighbourhood Poverty. An Analysis of Neighbourhood Histories of Individuals. Transactions of the Institute of British Geographers, 39, 402-417.

Van Ham, Maarten, and Manley, David. (2010). The Effect of Neighbourhood Housing Tenure Mix on Labour Market Outcomes: A Longitudinal Investigation of Neighbourhood Effects. Journal of Economic Geography, 10(2), 257-282.

Van Ham, Maarten, and Manley, David. (2012). Neighbourhood Effects Research at a Crossroads. Ten Challenges for Future Research. Environment and Planning A, 44(12), 2787-2793.

Van Kempen, Ronald, and Priemus, Hugo. (2002). Revolution in Social Housing in the Netherlands: Possible Effects of New Housing Policies. Urban Studies, 39(2), 237253.

Van Kempen, Ronald, and Wissink, Bart. (2014). Between Places and Flows: Towards a New Agenda for Neighbourhood Research in an Age of Mobility. Geografiska Annaler: Series B, Human Geography, 96(2), 95-108. 
Varady, David P. (1986). Neighborhood Upgrading: A Realistic Assessment. Albany, NY: State University of New York Press.

Warren, Donald I. (1981). Helping Networks: How People Cope with Problems in the Urban Community. Notre Dame, IN: Notre Dame University Press.

Whitehead, Christine, Scanlon, Kathleen, and Lunde, Jens. (2014). The Impact of the Financial Crisis on European Housing Systems: A Review. Stockholm, Sweden: Swedish Institute for European Policy Studies.

Wilson, James Q., and Kelling, George L. (1982). Broken Windows. Atlantic Monthly, 249(3), 29-38. 